\title{
Burden and modifications in life from the perspective of caregivers for patients after stroke ${ }^{1}$
}

\author{
Huana Carolina Cândido Morais² \\ Arethusa Morais de Gouveia Soares ${ }^{3}$ \\ Ana Railka de Souza Oliveira ${ }^{4}$ \\ Carolina Maria de Lima Carvalho ${ }^{5}$ \\ Maria Josefina da Silva ${ }^{6}$ \\ Thelma Leite de Araujo ${ }^{7}$
}

Objective: to analyze the impact that caring has on a member of the family caring for a patient after a cerebrovascular accident, correlating life modifications and mental suffering with the perceived burden. Method: a cross-sectional, quantitative study, undertaken in January-April 2010 in Fortaleza, Ceará, Brazil. Result: 61 individuals were investigated, monitored by three hospitals' Home Care Program. Data collection was through interviews for identifying life changes, and through the application of three scales for investigating perceived burden, mental state and mental suffering. Respectively these were the Caregiver Burden Scale (CBS), the Mini-Mental State Examination (MMSE) and the Self Reported Questionnaire (SRQ). The majority of the carers were female, married, and the children of the stroke patients. The average age was 48.2 years ( \pm 12.4$)$. The most-cited life modifications referred to the daily routine, to leisure activities, and to exhaustion or tiredness. Regarding burden, the dimensions of General tension, Isolation and Disappointment stood out. It was ascertained that overload was more severe when the carer presented more symptoms of psychological distress, in the absence of a secondary carer, and when the principal carers reported perceiving changes in their bodies and health. Conclusion: an association between burden and the carer's mental state was not observed. Understanding the care, through analysis of the burden and of the knowledge of the biopsychosocial situation will provide support for the nurse's work in reducing the overload for family caregivers.

Descriptors: Caregivers; Stroke; Nursing.

\footnotetext{
1 Paper extrated from Master's Thesis "Desafio do cuidado domiciliar: avaliação da sobrecarga de cuidadores de pacientes acometidos por acidente vascular encefálico", presented to Universidade Federal do Ceará, Brazil. Supported by Conselho Nacional de Desenvolvimento Científico e Tecnológico (CNPq), Brazil, Process \# 472570/2009-9.

2 Master's Student, Universidade Federal do Ceará, Brazil. Scholarship holder, Fundação Cearense de Apoio do Desenvolvimento Científico e Tecnológico (FUNCAP), Brazil.

${ }^{3}$ RN, Prefeitura Municipal de Fortaleza, Brazil. Master's Student, Universidade Federal do Ceará, Brazil.

${ }^{4}$ Doctoral Student, Universidade Federal do Ceará. Scholarship holder, Coordenação de Aperfeiçoamento de Pessoal de Nível Superior (CAPES), Brazil.

5 Post-doctoral fellow, Universidade Federal do Ceará. Scholarship holder, CAPES, Brazil.

${ }^{6} \mathrm{PhD}$, Associate Professor, Universidade Federal do Ceará, Brazil.

7 PhD, Full Professor, Universidade Federal do Ceará, Brazil.
} 


\section{Sobrecarga e modificações de vida na perspectiva dos cuidadores de pacientes com acidente vascular cerebral}

Objetivo: analisar o impacto do cuidar para o cuidador familiar de paciente após acidente vascular cerebral (AVC), correlacionando modificações de vida e sofrimento psíquico com a sobrecarga percebida. Método: estudo transversal, quantitativo, realizado de janeiro a abril de 2010, em Fortaleza, Ceará, Brasil. Resultado: investigaram-se 61 indivíduos, acompanhados pelo Programa de Atendimento Domiciliar (PAD), de três hospitais. A coleta dos dados ocorreu mediante entrevista para identificar modificações de vida, e com a aplicação de três escalas para investigar sobrecarga percebida, estado mental e sofrimento psíquico. São elas, respectivamente: Caregiver Burden Scale (CBS), Miniexame do Estado Mental (MEEM) e Self Reported Questionnaire (SRQ). Os cuidadores, na sua maioria, eram do sexo feminino, casados(as) e filho(as) dos pacientes após AVC. A média de idade era de 48,2 anos $( \pm 12,4)$. As modificações de vida mais citadas foram referentes à rotina diária, às atividades de lazer e esgotamento ou cansaço. Quanto à sobrecarga, destacaram-se as dimensões tensão geral, isolamento e decepção. Verificou-se maior sobrecarga quanto mais sintomas de sofrimento psíquico o cuidador apresentasse, na ausência de cuidador secundário e quando os cuidadores principais relataram perceber modificação no corpo e na saúde. Conclusão: não foi observada associação da sobrecarga com o estado mental do cuidador. Entender a conjuntura do cuidado, mediante análise da sobrecarga de trabalho, e do conhecimento da situação biopsicossocial fornecerá subsídios para a atuação do enfermeiro para reduzir a carga gerada para os cuidadores familiares.

Descritores: Cuidadores; Acidente Vascular Cerebral; Enfermagem.

\section{Sobrecarga y modificaciones de vida en la perspectiva de los cuidadores de pacientes con accidente vascular cerebral}

Objetivo: analizar el impacto del cuidar para el cuidador familiar de paciente después de accidente vascular cerebral, correlacionando modificaciones de vida y sufrimiento psíquico con la sobrecarga percibida. Método: estudio transversal, cuantitativo, realizado de enero a abril de 2010, en Fortaleza, Ceará, Brasil. Resultado: se investigaron 61 individuos, acompañados por el Programa de Servicio Domiciliar de tres hospitales. La colecta de los datos ocurrió mediante entrevista para identificar modificaciones de vida, y con la aplicación de tres escalas para investigar la sobrecarga percibida, estado mental y sufrimiento psíquico. Son ellas, respectivamente: Caregiver Burden Scale (CBS), Mini Examen del Estado Mental (MEEM) y Self Reported Questionnaire (SRQ). Los cuidadores, en su mayoría, eran del sexo femenino, casados (as) e hijo (as) de los pacientes después del AVC. Edad Media de 48,2 años $( \pm 12,4)$. Las modificaciones de vida más citadas fueron referentes a la rutina diaria, a las actividades de ocio y agotamiento o cansancio. En cuanto a la sobrecarga, se destacaron las dimensiones Tensión general, Aislamiento y Decepción. Se verificó mayor sobrecarga cuanto más síntomas de sufrimiento psíquico el cuidador presentase, en la ausencia de cuidador secundario y cuando los cuidadores principales relataron percibir modificación en el cuerpo y en la salud. Conclusión: no fue observada asociación de la sobrecarga con el estado mental del cuidador. Entender la coyuntura del cuidado, mediante análisis del recargo de trabajo, y del conocimiento de la situación biopsicosocial, suministrará subsidios para la actuación del enfermero para reducir la carga generada para los cuidadores familiares.

Descriptores: Cuidadores; Accidente Cerebrovascular; Enfermería.

\section{Introduction}

The care offered by family members to patients at home is a reality, as when the latter leave hospital institutions after a cerebrovascular accident (CVA), they still need special care. This occurs because the majority of the population's financial resources do not allow them to add to the monthly budget the cost of contracting a company or private health care professional trained to provide care in the home ${ }^{(1)}$. It follows that the need 
to care is more of a circumstantial imposition than a choice.

The figure of the caregiver emerges from family relations, which are almost always weakened by the presence of the condition and by what has been experienced. In this way meeting the dependent person's needs requires severe and profound arrangements in the intrafamily organization and dynamics.

In the face of this scenario, studies have shown that the compromising of cognitive function, presence of depression and problems of memory or functional capacity in patients following stroke worsen the overload of family carers ${ }^{(2-3)}$.

Burden may be seen as a multidimensional concept which encompasses the biopsychosocial sphere and results from the search for balance between the following variables: time available for caring, financial resources, psychological/physical/social conditions, and assignment and distribution of roles ${ }^{(4-5)}$.

Thus, the emotional impact experienced by the caregiver can interfere in the care given to the patient, and constitute a predictive factor for a higher number of hospitalizations among the patients( ${ }^{(6)}$, for an increase in institutionalization ${ }^{(7)}$, and higher mortality among the carers $^{(8)}$. As a consequence, the carers are challenged by innumerable demands, both foreseeable and not, resulting from the reduction in functional capacity of the patient being cared for, in conjunction with the presence of multiple factors inherent to the act of caring.

Surveys such as the present one can contribute to improving nursing care by making it more qualified and more directed at the needs of the populations studied, as the majority of works address the assistance offered to carers for elderly patients, and do not evaluate specific cases such as CVA, which entail repercussions for the caregivers.

Thus it becomes essential for nursing to review how it shall work with carers, considering that this is now a recognized occupation, active in various scenarios. The nurse may consider carers to be members of the nursing team, and train them so as to minimize their burden and improve the care offered to the dependent patient.

The study elaborated here is justified by the epidemiological relevancy of stroke which, in 2003, in the Northeast of Brazil, reached a mortality level of $54.6 / 100$ thousand inhabitants $^{(9)}$. In the municipality of Fortaleza, in 2008, individuals struck by CVAs formed $25.4 \%$ of the total of hospitalizations of individuals over 40 years of age in the Unified Health System ${ }^{(10)}$. CVAs' potential for establishing disabilities which cause tension in the role of the carer, and the scarcity in the literature of works focusing on the carers of patients with this condition, form part of this picture.

It follows that investigations are necessary for broadening knowledge about the events which compose the phenomena of burden among caregivers, based on the subjects' experiences; and it becomes essential to provide appropriate support for the carers with a view to minimizing problems and improving their quality of life. Thus the present study's objective was to analyze the impact of caring on the life of family members caring for patients after stroke, correlating life changes and psychological distress with perceived overload.

\section{Method}

This is a cross-sectional study, undertaken with family members caring for patients after CVAs, monitored by the Home Care Program of three tertiary care hospitals in Fortaleza, in the state of Ceará, in the period January-April 2010. The three programs' care teams were multidisciplinary, and carried out activities such as the appropriate medical care and interventions with the families of patients who were unable to leave the house for outpatient treatment.

The study included the principal family carers, who had been carrying out the role of carer for at least two months. It excluded family carers who were caring for patients who, in addition to a CVA, also had mental disorders or other neurological conditions, or who were alcoholics or drug addicts.

For the sample, a formula was used which is indicated for studies in which the variable 'outcome' is the average of a scale. Hence, the sample size was defined based on a confidence coefficient of $95 \%$ and an absolute sampling error of 0.126 points, based on the value for overload of carers for stroke patients as measured by the Caregiver Burden Scale (CBS) in a previous study ${ }^{(11)}$; the choice of using that study was made due to the absence of works in Brazil evaluating burden in this population with the above-mentioned scale.

The participating group was chosen for convenience and consecutively. For data collection, the authors used a form structured for investigating sociodemographic data (sex, age in years, marital status, schooling in years, degree of relatedness to the patient). The participants' clinical profiles and the principal modifications to their daily routine were reported through interviews.

The Mini Mental State Examination (MMSE) was used to evaluate cognitive state. This is comprised of 
various questions grouped into seven categories, which evaluate specific cognitive functions, such as: orientation in time and space, registration of three words, attention and calculation, recall of three words, language and constructive visual capacity(12). The identification of psychiatric symptoms was measured by means of the Self Reported Questionnaire (SRQ), previously validated for Brazil(13). The SRQ-20 detects psychiatric morbidity in the general population. The 20 questions which make up the scale were designed to address emotional and physical symptoms associated with psychiatric conditions.

The CBS was adopted for evaluating overload, because it measures the subjective impact of illness on carers, with intra- and interobservability reproducibility coefficients of 0.92 and 0.87 , respectively ${ }^{(14)}$.

The CBS is comprised of 22 questions, grouped in five dimensions (General tension, Isolation, Disappointment, Emotional involvement and Environment). Responses to the questions may vary from 1 to 4 , where: $1=$ never; 2 = rarely; 3 = sometimes; 4 = frequently. For measuring caregiver burden, the total score is obtained by the arithmetical average of the values equivalent to the responses to the 22 questions. The individual score is obtained based on the arithmetical average of the values equivalent to the responses to the specific questions of each dimension. There is no cut-off point for classifying

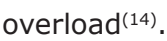

For identifying the principal modifiers of carers' daily routines, the authors partially used items from a scale for measuring overload among psychiatric patients' family members(15), as well as the defining characteristics of the nursing diagnosis of Caregiver role strain, from NANDA-International (NANDA-I)(16).

In November 2009, the instrument constructed was submitted to three judges, specialists in the care of stroke patients or who worked with the issue of caregivers of dependent patients, who evaluated the instrument's appearance and whether the construct responded to the research question. All the suggestions proposed were adopted and contributed to refining the data collection instruments.

The data was collected by nurses and student nurses in their final semester, who had previously received training addressing the research's theoretical content and the instrument's application. The instrument was subjected to a pilot test with four caregivers who were excluded from the study. The results were compiled in an Excel 8.0 spreadsheet, and processed and analyzed with the assistance of the Statistical Package for Social Sciences (SPSS) software, version 15.0. The level of significance adopted for all the tests was $5 \%(p<0.05)$.

The authors then proceeded to analysis using descriptive statistics, with distribution of absolute and relative frequencies for the categorical variables, and calculation of the averages and standard deviation for the continuous variables. The Shapiro-Wilk test and the Kolmogorov-Smirnov test were used for verification of the data's normality. Based on these tests' results, the T-test or Mann-Whitney testy was applied for ascertaining the average/median difference between two groups, and the Kruskal-Wallis test for ascertaining the difference between three or more groups. Spearman's correlation coefficient was calculated for measuring the correlation between the numerical variables.

The ethical principles for research involving human beings were met, in accordance with Resolution 196/96 of the National Health Council, and the study was approved by the Federal University of Ceará's Research Ethics Committee, under protocol number 310/09.

\section{Results}

Sixty-one carers participated in the study, all caring for stroke patients being monitored by the Home Care Program of tertiary hospitals in Fortaleza/Ceará. Table 1 presents the data on the caregivers' sociodemographic characterization.

Table 1 - Sociodemographic data of family carers for stroke patients. Fortaleza, CE, Brazil, 2010

\begin{tabular}{lll}
\hline \multicolumn{1}{c}{ Variables } & N & $\%$ \\
\hline Sex & & 93.4 \\
Female & 57 & 06.6 \\
Male & 04 & 52.5 \\
Marital status & & 32.8 \\
Married & 32 & 09.8 \\
Single & 20 & 04.9
\end{tabular}


Table 1 - (continuation)

\begin{tabular}{|c|c|c|c|c|c|c|}
\hline Variables & \multicolumn{3}{|c|}{$\mathbf{N}$} & \multicolumn{3}{|c|}{$\%$} \\
\hline \multicolumn{7}{|l|}{ Carer/patient relationship } \\
\hline Son/daughter & & 31 & & & 50.8 & \\
\hline Spouse & & 15 & & & 24.6 & \\
\hline Grandson/daughter & & 06 & & & 09.8 & \\
\hline Son-/daughter-in-law & & 03 & & & 04.9 & \\
\hline Nephew/niece & & 02 & & & 03.3 & \\
\hline Neighbor & & 02 & & & 03.3 & \\
\hline Parents & & 02 & & & 03.3 & \\
\hline \multicolumn{7}{|l|}{ Work } \\
\hline No & & 50 & & & 82.0 & \\
\hline Yes & & 11 & & & 18.0 & \\
\hline \multicolumn{7}{|c|}{ Can rely on external financial support } \\
\hline No & & 34 & & & 55.7 & \\
\hline \multirow[t]{2}{*}{ Yes } & & 27 & & & 44.3 & \\
\hline & Average & SD* $^{*}$ & Median & $\mathbf{P}^{2} 5^{\dagger}$ & P75 & p Valor \\
\hline Age (years) & 48.2 & 14.9 & 49.0 & 38.5 & 61.5 & 0.808 \\
\hline Schooling (years) & 08.8 & 04.5 & 11.0 & 05.0 & 12.0 & 0.029 \\
\hline Time as carer (months) & 49.1 & 57.8 & 27.0 & 05.0 & 84.0 & 0.013 \\
\hline Time spent with patient (hours) & 18.2 & 06.1 & 18.0 & 12.0 & 24.0 & 0.000 \\
\hline
\end{tabular}

* Standard Deviation. † Percentile 25. ₹ Percentile 75. § Kolmogorov-Smirnov test.

The majority of carers were female (93.4\%), married $(52.5 \%)$ and the son/daughter of the stroke patient $(50.8 \%)$. The average age was 48.2 years $( \pm 12.4)$, varying from a minimum age of 38.5 years (P25) up to 61.5 years (P75). The variables schooling, time as a carer and time spent per day with the patient presented asymmetric distribution ( $p$ value $<0.05$ ). According to the findings, half of the sample had been to school for up to 11 years, had been caring for 27 months and dedicated 18 hours per day to the activity of caring.

Besides this, regarding the occupational situation, $82 \%$ did not work, of whom 21 (42.9\%) had stopped working in order to become caregivers; 11 (22.4\%) were housewives; and 10 (20.4\%) were retired, according to the carers' reports.

Regarding being able to rely on external financial support to care for the patient after the stroke, 55.7\% reported not being able to rely on any type of financial support. Of those who did receive support, however, it was usually cited as coming from the family (68\%) and on a monthly basis ( $88 \%$ ).

In addition to the principal family carers, $72.1 \%$ of the patients had a secondary carer to help in the work and $26.2 \%$ paid somebody to assist with the care; $36.1 \%$ relied on an occasional caregiver. In addition to the stroke patients' problems, the caregivers also mentioned their own illnesses. Table 2 presents the carers' clinical profile.

Table 2 - Clinical profile of post-CVA patients' carers. Fortaleza, CE, Brazil, 2010

\begin{tabular}{|c|c|c|c|c|}
\hline \multirow{2}{*}{ Variables } & \multicolumn{2}{|c|}{ Present } & \multicolumn{2}{|c|}{ Absent } \\
\hline & $\mathbf{N}$ & $\%$ & $\mathbf{N}$ & $\%$ \\
\hline Hypertension & 17 & 27.9 & 44 & 72.1 \\
\hline Diabetes mellitus & 07 & 11.5 & 54 & 88.5 \\
\hline Heart disease & 01 & 01.6 & 60 & 98.4 \\
\hline Dyslipidemia & 07 & 11.5 & 54 & 88.5 \\
\hline Osteoporosis & 06 & 09.8 & 55 & 90.2 \\
\hline \multirow{2}{*}{ Variables } & \multicolumn{2}{|c|}{ Normal } & \multicolumn{2}{|c|}{ Altered } \\
\hline & $\mathbf{N}$ & $\%$ & $\mathbf{N}$ & $\%$ \\
\hline MMSE caregiver & 34 & 55.7 & 27 & 44.3 \\
\hline SRQ-20 Classification & 34 & 55.7 & 27 & 44.3 \\
\hline
\end{tabular}

(continue...) 
Table 2 - (continuation)

\begin{tabular}{|c|c|c|c|c|c|c|}
\hline Variables & Average & SD* $^{*}$ & Median & $\mathrm{P}^{2} 5^{\dagger}$ & $\mathrm{P} 75^{*}$ & p value s $^{\S}$ \\
\hline Duration of DM (in months) & 55.2 & 52.0 & 48.0 & 18.0 & 096.0 & 0.554 \\
\hline Duration of Hypertension (in months) & 72.0 & 72.2 & 39.0 & 13.5 & 120.0 & 0.249 \\
\hline Duration of Osteoporosis (in months) & 19.0 & 21.3 & 10.0 & 06.5 & 033.0 & 0.531 \\
\hline Duration of dyslipidemia (in months) & 37.8 & 49.3 & 04.5 & 12.0 & 084.0 & 0.761 \\
\hline SRQ-20 & 06.9 & 04.2 & 06.0 & 03.5 & 011.0 & 0.305 \\
\hline MMSE carer & 26.0 & 03.4 & 27.0 & 24.0 & 029.0 & 0.319 \\
\hline
\end{tabular}

* Standard Deviation. † Percentile 25. $\neq$ Percentile 75. § Kolmogorov-Smirnov test.

Regarding clinical situations which present a higher risk for the development of illnesses, the most frequent illness was hypertension (27.9\%). Furthermore, in $75 \%$ of the carers with this illness, it had already been present for 120 months. Other morbidities, such as diabetes mellitus and dyslipidemias were present in $11.5 \%$ of the participants, respectively, while osteoporosis was mentioned by $9.8 \%$ of them. Besides these alterations, some caregivers mentioned problems such as depression, circulatory disorders and thyroid disorders. Regarding the variables of durations of the illnesses, all presented symmetric distribution ( $p$ value $>0.05$ ).
When cognitive state was evaluated, an average of 26.0 points $( \pm 3.44)$ was obtained, and $44.3 \%$ presented an altered cognitive level, according to the relationship between the level of schooling and the MMSE score.

According to the SRQ-20, 44.3\% showed some degree of mental suffering, whose average was 6.9 points $( \pm 4.2)$. The psychiatric symptoms present in more than $50 \%$ included: feeling short-tempered, tense or worried $(73.8 \%)$, sleeping badly $(63.9 \%)$, and having felt sad recently (55.7\%). No carers, however, stated that they felt useless or valueless. Table 3 presents the results obtained by applying the Caregiver Burden Scale.

Table 3 - Global score and score of the dimensions of the CBS. Fortaleza, CE, Brazil, 2010

\begin{tabular}{|c|c|c|c|c|c|c|}
\hline Variables & Average & SD* & Median & $\mathbf{P} 25^{\dagger}$ & $\mathrm{P} 75^{\ddagger}$ & K-S ( $p$ value) $)^{\S}$ \\
\hline Average CBS & 2.3 & 0.5 & 2.4 & 1.9 & 2.8 & 0.381 \\
\hline Average General tension & 2.7 & 0.8 & 2.8 & 2.1 & 3.5 & 0.343 \\
\hline Average Isolation & 2.7 & 1.0 & 3.0 & 2.0 & 3.6 & 0.076 \\
\hline Average Disappointment & 2.5 & 0.8 & 2.6 & 2.0 & 3.1 & 0.874 \\
\hline Average Environment & 2.1 & 0.6 & 2.0 & 1.6 & 2.6 & 0.216 \\
\hline Average Emotional involvement & 1.6 & 0.7 & 1.3 & 1.0 & 2.0 & 0.002 \\
\hline
\end{tabular}

* Standard Deviation. + Percentile 25. ₹ Percentile 75. § Kolmogorov-Smirnov test.

In relation to the measurement of caregiver burden of patients after stroke, the general average of the CBS was $2.3( \pm 0.5)$. The dimensions presented symmetrical distribution ( $\mathrm{p} 0.05)$, apart from Emotional involvement, which showed asymmetric distribution, and half of the population attained a score of 1.3 for this item. The dimensions with the highest values of burden were General tension, Isolation and Disappointment, with averages of $2.7,2.7$ and 2.5 respectively. Table 4 lists the principal life changes felt by family caregivers of stroke patients.

Table 4 - Changes in the lives of family carers for stroke patients. Fortaleza, CE, Brazil, 2010

\begin{tabular}{|c|c|c|}
\hline Changes in the lives of the caregivers & $\mathbf{N}$ & $\%$ \\
\hline More or less permanent changes in daily routine & 53 & 86.9 \\
\hline Social or leisure activities were altered or disturbed & 49 & 80.3 \\
\hline Feeling exhaustion or tiredness & 48 & 78.7 \\
\hline Home routines were altered or disrupted & 46 & 75.5 \\
\hline Caring for the family member stops you dedicating time and attention to other members of the family & 45 & 73.8 \\
\hline You have felt some change in your emotional state since starting to care for the patient & 45 & 73.8 \\
\hline You feel pain in your body & 43 & 70.5 \\
\hline
\end{tabular}


Table 4 - (continuation)

\begin{tabular}{|c|c|c|}
\hline Changes in the lives of the caregivers & $\mathbf{N}$ & $\%$ \\
\hline You have been late for, or cancelled, some engagement & 41 & 67.2 \\
\hline You have stopped enjoying holidays & 40 & 65.6 \\
\hline You have felt changes in your body or health since starting activities as a carer & 40 & 65.6 \\
\hline You have stopped receiving (or receive fewer) guests at home & 30 & 49.2 \\
\hline You have stopped having a harmonious relationship with other family members & 29 & 47.5 \\
\hline You work less, or quit work, or had to work more to cover costs & 28 & 45.9 \\
\hline You have lost friendships & 19 & 31.1 \\
\hline You feel depressed & 19 & 31.1 \\
\hline You have retired early & 05 & 08.2 \\
\hline
\end{tabular}

The change cited most frequently by the carers referred to their daily routine $(86.9 \%)$, followed by changes to leisure activities (80.3\%), exhaustion or tiredness $(78,7 \%)$, problems related to home routines (75.5\%) and not being able to dedicate time and attention to other members of the family $(73.8 \%)$.

Among the changes to daily routine, $70.5 \%$ mentioned lack of free time for watching TV, reading, or visiting friends or relatives; $65.6 \%$ said that they lacked free time for going to the bank, going shopping or going to the doctor; $57.4 \%$ couldn't manage to do household chores; $50.9 \%$ didn't have time for eating; and $36.1 \%$ said they lacked the free time for taking a bath.

$78.3 \%$ of the caregivers reported having noticed some changes in their emotional state since starting caring for the patient. Further, feeling pains in the body was reported by $70.5 \%$. Of these, $69.8 \%$ stated that the pain started after the patient's dependency became established and $83.7 \%$ said that the pain continued after carrying out activities. Regarding the location of the pain, the back (30.2\%) and back and legs (20.9\%) were the most mentioned. Table 5, below, shows the statistics of correlation between the caregivers' characteristics and the average on the CBS.

Table 5 - Distribution of statistics of association and correlation between the characteristics of the carers for stroke patients and the average on the Caregiver Burden Scale. Fortaleza, CE, Brazil, 2010

\begin{tabular}{|c|c|c|c|}
\hline Variables & Average & SD & p Value (T-test) \\
\hline \multicolumn{4}{|l|}{ HAS } \\
\hline Yes & 2.3 & 0.6 & 0.871 \\
\hline No & 2.3 & 0.5 & \\
\hline \multicolumn{4}{|l|}{ Caring for other person } \\
\hline Yes & 2.4 & 0.7 & 0.579 \\
\hline No & 2.3 & 0.5 & \\
\hline \multicolumn{4}{|l|}{ MMSE Carer Classification } \\
\hline Normal & 2.4 & 0.5 & 0.444 \\
\hline Altered & 2.3 & 0.6 & \\
\hline Variables & \multicolumn{2}{|c|}{ Average of the ranks } & p Value (Mann-Whitney test) \\
\hline \multicolumn{4}{|l|}{ Sex } \\
\hline Male & \multicolumn{2}{|c|}{26.5} & 0.600 \\
\hline Female & \multicolumn{2}{|c|}{31.3} & \\
\hline \multicolumn{4}{|l|}{ Marital situation } \\
\hline With companion & \multicolumn{2}{|c|}{26.4} & 0.058 \\
\hline Without companion & \multicolumn{2}{|c|}{35.0} & \\
\hline \multicolumn{4}{|l|}{ Working } \\
\hline Yes & \multicolumn{2}{|c|}{25.7} & 0.277 \\
\hline No & \multicolumn{2}{|c|}{32.1} & \\
\hline \multicolumn{4}{|l|}{ Family receiving help } \\
\hline Yes & \multicolumn{2}{|c|}{29.5} & 0.576 \\
\hline No & \multicolumn{2}{|c|}{32.1} & \\
\hline
\end{tabular}


Table 5 - (continuation)

\begin{tabular}{|c|c|c|}
\hline Variables & Average of the ranks & p Value (Mann-Whitney test) \\
\hline \multicolumn{3}{|l|}{ Diabetes Mellitus } \\
\hline Yes & 25.0 & 0.342 \\
\hline No & 31.7 & \\
\hline \multicolumn{3}{|l|}{ Osteoporosis } \\
\hline Yes & 36.4 & 0.431 \\
\hline No & 30.4 & \\
\hline \multicolumn{3}{|l|}{ Dyslipidemia } \\
\hline Yes & 26.2 & 0.448 \\
\hline No & 31.6 & \\
\hline \multicolumn{3}{|c|}{$\begin{array}{l}\text { Have you felt changes in your body } \\
\text { or health since starting activities as a } \\
\text { carer }\end{array}$} \\
\hline Yes & 35.1 & 0.005 \\
\hline No & 21.9 & \\
\hline Variables & $\mathbf{R}$ & p Value (Spearman's test) \\
\hline Carer's age & 0.220 & 0.089 \\
\hline Schooling & -0.037 & 0.779 \\
\hline Time as carer & 0.202 & 0.118 \\
\hline Time spent with patient & 0.201 & 0.121 \\
\hline SRQ-20 & 0.586 & 0.000 \\
\hline MMSE & -0.014 & 0.912 \\
\hline
\end{tabular}

There was a positive correlation between the average of the SRQ-20 for psycho-emotional disorders in the carer and the CBS average $(p=0.000)$. On comparing the average of the ranks for the item 'Have you felt changes in your body or health since starting activities as a carer' with the CBS average, according to what was observed, those carers who reported some change had higher overload values $(p=0.005)$.

\section{Discussion}

Regarding the sociodemographic data it may be seen that it was predominantly women who were responsible for the care $(93.4 \%)$, corroborating a previous study which highlights the role of the woman as carer, principally in the family setting ${ }^{(17)}$. The number of sons/daughters who were principal family carers (50.8\%) was also significant. In this aspect, the feeling of retribution may be present, as the majority of women are more emotional.

The marital status of the carer also requires attention, as spouses end up experiencing the same problems as the patients, such as changes in lifestyle, frustration, loss of independence, loss of confidence, and feelings of uselessness and solitude ${ }^{(18)}$. The majority of carers were married $(52.5 \%)$, which can be a positive factor, when it constitutes support for the activities carried out, or negative, when it creates burden on the carer due to the accumulation of roles.
Financial difficulties are another problem, reported by $59 \%$ of the interviewees. Some of the family carers have problems with their job, finally having to give it up or reduce work hours so as to dedicate more time to the individual after the stroke ${ }^{(18)}$. In the present study, the majority of the carers did not undertake paid activity $(82 \%)$ outside the home, or receive external financial support (34\%); in $42.9 \%$ of the cases, the carer stopped working so as to care for the stroke patient full time.

The carers need to adapt to a new, unexpected and intense routine of care, facing economic and structural difficulties and needing support(19). This formal and informal social support network must be comprised of institutions, public and private official services, and networks of friends or volunteers, who act as facilitators for controlling problematic situations ${ }^{(20)}$.

In a general way, the family carers caring for individuals after stroke experience significant changes in their lifestyles that reduce, change or create discontent in their lives, creating feelings of isolation. Among the principal factors which limit their social lives are: overload of activities, loss of a companion in social activities, behavioral disorders in the patient after a CVA, changes in family relationships and in the circle of friends, and - from the new neighborhood - isolation and reluctance to provide support ${ }^{(18)}$.

In the literature, one can see a consensus on the distinction between objective and subjective overload. The first refers to the events perceived by the carers 
to be related to the performance of their role, while the second refers to feelings and attitudes inherent to the care process ${ }^{(20)}$. Burden can also be observed in the physical, emotional and social settings. In the present study, the levels of overload were high, and the categories of General tension, Isolation and Disappointment stand out. A study undertaken with the carers of patients after stroke in Cartagena, Colombia, found that physical well-being is the most impaired, with muscle fatigue and altered sleeping patterns being the aspects most affected in the caregivers ${ }^{(21)}$.

It may be seen that the lack of free time for leisure, friends and common, day-to-day things, the sensation of imprisonment, the exclusive dedication, in some cases, without being able to share the care provision with another person, and the physical tiredness due to the overload of activities are facts commonly observed in the routine of people who care for patients after stroke. These situations create family conflicts, due to the solitude and social exclusion of the caregivers ${ }^{(1)}$.

Psychological and emotional burden were investigated, which are not always expressed spontaneously by the carers. A study determined that carers for the elderly are at greater risk of psychiatric and physical morbidity if compared to the general population ${ }^{(17)}$. This situation is aggravated by the existence of a further incapacitating condition such as stroke.

Another problem was mentioned, that is, that $44.3 \%$ showed alterations in the cognitive state and/or some psychological distress. The fact of being depressed can cause the carer more difficulty in reinserting the patient into society ${ }^{(22)}$.

In the face of this reality, carers constitute a sociallyand economically-deprived group, with limited access to areas of leisure or culture, with low levels of schooling, affected by chronic illnesses, and reliant almost exclusively on an informal, family support network. This overload can entail physical, psychological, emotional, social and financial problems, with consequences for the well-being of both the patient and carer.

The hypothesis according to which carers are at greater risk of developing various health problems such as high levels of depression, anxiety and physical complaints - was confirmed in this study, as the psychoemotional disorders measured by the SRQ-20 were found in $44.3 \%$ of the carers for patients after CVA. This is, therefore, above the rate of $22.7 \%$ found in a populational study of normal people resident in the city of Pelotas in Rio Grande do Sul ${ }^{(23)}$ and above the rate of
$32.2 \%$ found among carers caring for dependent elderly people(24).

A previous study(25), like the present study, did not identify any association of the age or sex of the carer with the presence of overload. There was, however, an association between the presence of psychiatric symptoms and the increase in overload.

The role of preventing losses and damage to health should equally include the figure of the carer. Thus, programs must be developed aimed at preventing overload and negative emotional impact which can affect the carer's health and quality of life. The nurse must hold an active role in the development of these activities.

The present study was limited by its methodological design, which did not include follow-up of the activities performed by the carers, and by the fact that these were in the Home Care Program, which does not correspond to the reality of the majority of patients after a stroke.

\section{Conclusion}

A CVA can bring grave repercussions to the patients, their families and to society. Understanding the picture of care, through analysis of overloading of work and of the knowledge of the biopsychosocial situation, will provide support for the work of the nurse in reducing the load created for family carers. It is worth highlighting the importance of knowing the principal difficulties faced by these individuals, so that new policies may be designed to attend this population.

\section{References}

1. Lavinsky AE, Vieira TT. Processo de cuidar de idosos com acidente vascular encefálico: sentimentos dos familiares envolvidos. Acta Sci Health Sci. 2004;26(1):41-5.

2. May $H L$, Lui M, Ross FM, Thompson DR. Supporting family caregivers in stroke care. A review of the evidence for problem solving. Stroke. 2005;36:2514-22.

3. Mccullagh E, Brigstocke G, Donaldson N, Kalra L. Determinants of Caregiving Burden and Quality of Life in Caregivers of Stroke Patients. Stroke. 2005;36:2181-6. 4. Sherwood PR, Given CW, Given BA, Eye AV. Caregiver burden and depressive symptoms. J Aging Health. 2005;17(2):125-47.

5. Hankey GJ. Informal care giving for disabled stroke survivors. BMJ. 2004;328:1085-108.

6. Balardy L. Predictive factors of emergency hospitalisation in Alzheimer's patients: results of oneyear follow-up in the REAL.FR Cohort. J Nutr Health Aging. 2005;9:112-6. 
7. Torti FM, Gwyther LP, Reed SD, Friedman JY, Schulman KA. A multinational review of recent trends and reports in dementia caregiver burden. Alzheimer Dis Assoc Disord. 2004;18:99-109.

8. Patterson TL, Grant I. Interventions for caregiving in dementia: physical outcomes. Curr Opin Psychiatr. 2003; 16:629-33.

9. Curioni C, Cunha CB, Veras RP, André C. The decline in mortality from circulatory diseases in Brazil. Pan Am J Public Health. 2009;25(1):9-15.

10. Secretaria de Saúde do Estado do Ceará (BR). Relatório dos indicadores de monitoramento e avaliação do pacto pela saúde 2008. Ceará; 2010.

11. Elmstahl S, Malmberg B, Annerstedt L. Caregiver's burden of patients 3 years after stroke assessed by a novel caregiver burden scale. Arch Phys Med Rehabil. 1996;77(2):177-82.

12. Ministério da Saúde (BR). Secretaria de Atenção à Saúde. Departamento de Atenção Básica. Envelhecimento e saúde da pessoa idosa. Brasília; 2006. 13. Mari JJ, Williams P. A validity study of a psichiatric screening questionnaire (SRQ20) in primare care in the city of São Paulo. Br J Psychiatry. 1986;148:23-6.

14. Medeiros MMC. Impacto da doença e qualidade de vida dos cuidadores primários de pacientes com artrite reumatóide: adaptação cultural e validação do Caregiver Burden Scale [tese doutorado]. São Paulo: Escola Paulista de Medicina da Universidade de São Paulo; 1998.

15. Bandeira M, Calzavara MG, Varella A. Escala de Sobrecarga dos Familiares de Pacientes Psiquiátricos FBIS-Br: Adaptação Transcultural para o Brasil. J Bras Psiquiatria. 2005;54(3):206-14.

16. NANDA International [NANDA-I]. Nursing diagnoses: Definitions \& classification, 2009-2011. Oxford (UK): Wiley-Blackwell; 2009.

17. Giacomin KC, Uchoa E, Lima CMF. Projeto Bambuí: a experiência do cuidado domiciliário por esposas de idosos dependentes. Cad Saúde Pública. 2005;21(5):1509-18. 18. Bocchi SCM. Vivenciando a sobrecarga ao vir-a-ser um cuidador familiar de pessoa com acidente vascular cerebral (AVC): análise do conhecimento. Rev. LatinoAm. Enfermagem. 2004;12(1):115-21.

19. Oliveira BC, Garanhani ML, Garanhani MR. Cuidador de pessoa com acidente vascular encefálico - necessidades, sentimentos e orientações recebidas. Acta Paul Enferm. 2011;24(1):43-9.
20. Martins T, Ribeiro JP, Garrett C. Estudo de validação do questionário de avaliação da sobrecarga para cuidadores informais. Psicol Saúde Doenças 2003;4(1):131-48.

21. Torres IEF, Prieto AM, Lián AH. Calidad de vida de cuidadores de adultos com acidente cerebrosvascular. Av Enferm. 2010;28(no esp):52-60.

22. Grant JS, Elliott TR, Weaver M, Bartolucci AA, Giger JN. Telephone intervention with family caregivers of stroke survivors after rehabilitation. Stroke. 2002;33:2060-5.

23. Tavares BF, Beria JU, Lima MS. Prevalência do uso de drogas e desempenho escolar entre adolescentes. Rev Saúde Pública. 2001;35(2):150-8.

24. Rezende TCB. Impacto do ato de cuidar na vida de cuidadores primários de idosos dependentes. [Dissertação de Mestrado]. Campinas: Faculdade de Ciências Médicas da Universidade Estadual de Campinas; 2008. 98 p.

25. Visser-Meily A, Post M, van de Port I, Maas C, Forstberg-Wärleby G, Lindeman E. Psychosocial functioning of spouses of patients with stroke from initial inpatient rehabilitation to 3 years poststroke. Stroke. 2009;40:1399-404. 